Article

\title{
Scandium and Titanium Recovery from Bauxite Residue by Direct Leaching with a Bronsted Acidic Ionic Liquid
}

\author{
Chiara Bonomi ${ }^{1, *(1)}$, Alexandra Alexandri ${ }^{1}$, Johannes Vind ${ }^{1,2} \oplus$, Angeliki Panagiotopoulou ${ }^{3,4}$, \\ Petros Tsakiridis ${ }^{1}$ (D) and Dimitrios Panias $1, *$ (D) \\ 1 School of Mining and Metallurgical Engineering, National Technical University of Athens, \\ Iroon Polytechniou 9, Zografou Campus, 15780 Athens, Greece; aalexandri@metal.ntua.gr (A.A.); \\ jvind@metal.ntua.gr (J.V.); ptsakiri@central.ntua.gr (P.T.) \\ 2 Department of Continuous Improvement and System Management, Aluminium of Greece Plant, \\ Metallurgy Business Unit, Mytilineos S.A., Agios Nikolaos, 32003 Viotia, Greece \\ 3 Institute of Biosciences \& Applications, National Centre for Scientific Research "Demokritos", \\ Patr. Gregoriou E \& 27 Neapoleos Str, Agia Paraskevi, 15310 Athens, Greece; apanagio@bio.demokritos.gr \\ 4 Institute of Biosciences \& Applications, National Centre for Scientific Research “Demokritos", Neapoleos 10, \\ Agia Paraskevi, 15310 Athens, Greece \\ * Correspondence: bonomich@metal.ntua.gr (C.B.); panias@metal.ntua.gr (D.P.); \\ Tel.: +30-210-7724054 (C.B. \& D.P.)
}

Received: 20 September 2018; Accepted: 15 October 2018; Published: 17 October 2018

check for updates

\begin{abstract}
In this study, bauxite residue was directly leached using the Brønsted acidic ionic liquid 1-ethyl-3-methylimidazolium hydrogensulfate. Stirring rate, retention time, temperature, and pulp density have been studied in detail as the parameters that affect the leaching process. Their optimized combination has shown high recovery yields of Sc, nearly $80 \%$, and $\mathrm{Ti}(90 \%)$, almost total dissolution of $\mathrm{Fe}$, while $\mathrm{Al}$ and $\mathrm{Na}$ were partially extracted in the range of 30-40\%. Si and rare earth element (REEs) dissolutions were found to be negligible, whereas Ca was dissolved and reprecipitated as $\mathrm{CaSO}_{4}$. The solid residue after leaching was fully characterized, providing explanations for the destiny of REEs that remain undissolved during the leaching process. The solid residue produced after dissolution can be further treated to extract REEs, while the leachate can be subjected to metal recovery processes (i.e., liquid-liquid extraction) to extract metals and regenerate ionic liquid.
\end{abstract}

Keywords: bauxite residue; red mud; ionic liquids; scandium recovery; titanium recovery

\section{Introduction}

Bauxite residue (BR), also known as red mud, is the major byproduct of the Bayer process for alumina production, produced by the alkali leaching of bauxite. On average, for each metric ton of alumina, 1-1.5 metric tons of BR are generated [1,2], which leads to a global production of over 150 million metric tons per year $[1,3]$.

BR composition can differ depending on the type of bauxite ore from which alumina are produced and Bayer processing techniques [4,5]. During the Bayer process, valuable base and trace elements like iron $(\mathrm{Fe})$, some aluminum $(\mathrm{Al})$, titanium $(\mathrm{Ti})$, and rare earth elements (REEs) remain in the bauxite residue. As a consequence, REEs are enriched with a factor of about 2 in BR comparing to the initial ore [6,7]. Particularly interesting is the case of scandium (Sc), as its concentration in BR (in Greek BR accounts to $130 \mathrm{ppm}$ on average) is much higher than in the Earth's crust (22 ppm on average [8]); that means a notable enrichment of Sc in BR. Due to the high market price $\left(\mathrm{Sc}_{2} \mathrm{O}_{3}-4600 \mathrm{US} \$ / \mathrm{kg}, 99.99 \%\right.$ purity, in 2017) [9], Sc may represent 95\% of the economic value of rare earths in BR [10]. It has also 
been listed as a critical raw material by the European Commission due to its high economic importance and supply risk [11]. In fact, Sc is mainly produced as a byproduct during the processing of various ores, from titanium and REEs ores (China), uranium ore (Kazakhstan and Ukraine), and apatite ore (Russia). It can also be recovered from previously processed tailings or residues $[9,12,13]$. For these reasons, BR can be accounted as a secondary raw material source [14], and the recovery of Sc could represent a high economic interest.

BR can also be considered a secondary source for Ti, which is a photocatalyst and it is applied in the white pigment industry [15]. Since the availabilities and qualities of Ti ores are decreasing [16], it is important to find methods for extracting Ti from secondary sources.

Many studies, patents, and pilot scale implementations have been carried out for Sc and Ti recovery from $\mathrm{BR}$, mainly by investigating hydrometallurgical or combined pyro-hydrometallurgical processes [5,12,16-23], but none of them has reached an industrial scale. Nowadays, the impact of the zero-waste valorization policy motivates the research community on finding innovative, greener, and economical viable routes for metal extraction from complex polymetallic matrices, such as the bauxite residue [24].

Ionometallurgical approach can be exploited as an alternative to conventional hydrometallurgical processing. The term ionometallurgy indicates the use of ionic liquids (ILs) as solvents in metals processing. ILs are liquid at room temperature and consist solely of ions; generally an organic cation and inorganic/organic anion. ILs have superior properties against conventional organic solvents, such as nonflammability, a wide electrochemical window, high thermal stability, negligible vapor pressure, and low volatility [25]. For these reasons and thanks to the vast number of combinations of the cation and the anion during synthesis, ILs have potential for many applications, such as solvent extraction [26,27], catalytic reactions [28,29], and electrodeposition of metals [30,31]. In the past few decades, ILs have been used also as lixiviants for metals dissolution [25,32-35]. Applying ionic liquid leaching on secondary raw material resources eventually improves efficiency yields, reduce waste effluent, and increases selectivity.

The aim of this work is to investigate the direct leaching of bauxite residue by using a Brønsted acidic ionic liquid, achieving high Ti and Sc recovery yields. To optimize the process, several parameters were studied. Moreover, solid residue after leaching was fully characterized and explanations of the destiny of REEs were given.

\section{Materials and Methods}

Bauxite residue was provided by Aluminium of Greece (Mytilineos S.A.), dried at $100{ }^{\circ} \mathrm{C}$ overnight, homogenized, and split in order to take a representative sample that was next crushed and ground. The sample was then subjected to chemical, mineralogical and physical characterization. Chemical composition was analyzed after complete dissolution of the sample via fusion method: $0.1 \mathrm{~g}$ of BR was mixed with $1.5 \mathrm{~g}$ of $\mathrm{Li}_{2} \mathrm{~B}_{4} \mathrm{O}_{7}$ and $0.1 \mathrm{~g}$ of $\mathrm{KNO}_{3}$ and then fused at $1000{ }^{\circ} \mathrm{C}$ for $1 \mathrm{~h}$, followed by dissolution in $\mathrm{HNO}_{3} 10 \% \mathrm{v} / \mathrm{v}$. The main elements were identified by a Perkin Elmer 2100 Atomic Absorption Spectrometer (AAS) (Waltham, MA, USA), while minor elements were analyzed by a Thermo Fisher Scientific ${ }^{\mathrm{TM}}$ X-series 2 Inductively Coupled Plasma Mass Spectrometer (ICP-MS) (Waltham, MA, USA) and a Perkin Elmer Optima 8000 Inductively Coupled Plasma Atomic Emission Spectrometer (ICP-OES) (Waltham, MA, USA). The calcium oxide content was measured in the solid sample with a Spectro Xepos Energy Dispersive X-ray fluorescence spectroscopy (SPECTRO, Kleve, Germany) (ED-XRF). Mineralogical characterization was performed with a Bruker D8 focus X-ray powder diffractometer (XRD) (Bruker, Billerica, MA, USA) with nickel-filtered CuKa radiation, and quantitative evaluation was done via profile fitting by using XDB Powder Diffraction Phase Analytical System version 3.107 that targets specifically bauxite and bauxite residue [36,37]. Particle size analysis was carried out by a Malvern Mastersizer TM Laser particle size analyzer (Malvern Instruments, Malvern, UK). 
The ionic liquid 1-ethyl-3-methylimidazolium hydrogensulfate ([Emim] $\left[\mathrm{HSO}_{4}\right]$ ) was supplied by Iolitec (Iolitec Ionic Liquids Technologies, Heilbronn, Germany) with $>98 \%$ purity and characterized. Infrared measurements were conducted with a Perkin Elmer FTIR spectrum 100 (Waltham, MA, USA). Viscosity analysis was performed with a Brookfield viscometer DV-I + LV supported by a Brookfield Thermosel accessory (Brookfield Ametek, Harlow, UK). Nuclear Magnetic Resonance (NMR) spectra were obtained in DMSO- $d_{6}$ at $25^{\circ} \mathrm{C}$ on a Bruker Avance DRX $500 \mathrm{MHz}$ (Bruker Biospin, Germany) $\left({ }^{1} \mathrm{H}\right.$ at $500.13 \mathrm{MHz}$ and ${ }^{13} \mathrm{C}$ at $\left.125.77 \mathrm{MHz}\right)$ equipped with a $5 \mathrm{~mm}$ multi nuclear broad band inverse detection probe.

Batch leaching experiments were performed in a $50 \mathrm{~mL}$ Trallero and Schlee mini reactor (Trallero and Schlee, Barcelona, Spain) combined with a mechanical stirrer, a vapor condenser, and a temperature controller, by adding BR to the IL when the set temperature was reached. Vacuum filtration was executed by cooling the system at $120^{\circ} \mathrm{C}$ and adding a nonviscous/volatile solvent (dimethyl sulfoxide, further denoted as DMSO) to the leachates, to decrease viscosity and ease the process. After filtration, pregnant leaching solutions (PLS) were digested through acidic treatment $\left(\mathrm{HNO}_{3} 65 \% v / v\right.$ and aqua regia) to oxidize and destroy the organics and then analyze with AAS, ICP-OES and ICP-MS. Solid residues were characterized via fusion method (already described above) and XRD. Microstructural characterization was carried out by a JEOL 6380 LV Scanning Electron Microscope (JEOL, Tokyo, Japan) coupled with Energy Dispersive System (SEM-EDS) and a JEOL 2100 HR (JEOL, Tokyo, Japan) 200 kV Transmission Electron Microscope (TEM) in order to detect and locate REEs.

\section{Results and Discussion}

\subsection{Bauxite Residue Characterization}

The main component of BR was found to be $\mathrm{Fe}_{2} \mathrm{O}_{3}$, accounting for 42.34 wt.\%, followed by $\mathrm{Al}_{2} \mathrm{O}_{3}$ with 16.25 wt. $\%$, while $\mathrm{TiO}_{2}$ was $4.27 \mathrm{wt} . \%$, and total rare earth oxides (REO) assessed to $0.19 \mathrm{wt} . \%$, as it is shown in Table 1.

Table 1. Bauxite residue chemical analysis. Note: REO, rare earth oxides; LOI, loss of ignition.

\begin{tabular}{ccccccccccc}
\hline Unit & $\mathrm{Fe}_{2} \mathrm{O}_{3}$ & $\mathrm{Al}_{2} \mathrm{O}_{3}$ & $\mathrm{SiO}_{2}$ & $\mathrm{TiO}_{2}$ & $\mathrm{CaO}$ & $\mathrm{Na}_{2} \mathrm{O}$ & $\mathrm{REO}$ & LOI & Others & Sum \\
\hline wt. $\%$ & 42.34 & 16.25 & 6.97 & 4.27 & 11.64 & 3.83 & 0.19 & 12.66 & 1.85 & 100.00 \\
\hline
\end{tabular}

In particular, cerium (Ce) was found to be the main rare earth element in concentration (402.2 mg/kg), followed by lanthanum (La) (145 mg/kg), scandium (Sc) (134 mg/kg), neodymium (Nd) $(127.1 \mathrm{mg} / \mathrm{kg})$, and yttrium (Y) $(112 \mathrm{mg} / \mathrm{kg})$.

Identification and quantification of mineralogical phases (Table 2) denoted hematite as the main mineral in BR with $30 \mathrm{wt}$ \%, while Ti-containing phases were perovskite, anatase and rutile with 4.5 , 0.5 and 0.5 wt. $\%$ respectively.

Table 2. Bauxite residue mineralogical phases and quantification.

\begin{tabular}{|c|c|c|}
\hline Mineralogical Phase & Formula & wt. $\%$ \\
\hline Hematite & $\mathrm{Fe}_{2} \mathrm{O}_{3}$ & 30 \\
\hline Calcium aluminum iron silicate hydroxide & $\mathrm{Ca}_{3} \mathrm{AlFe}\left(\mathrm{SiO}_{4}\right)(\mathrm{OH})_{8}$ & 17 \\
\hline Cancrinite & $\mathrm{Na}_{6} \mathrm{Ca}_{2}\left(\mathrm{AlSiO}_{4}\right)_{6}\left(\mathrm{CO}_{3}\right)_{2}$ & 15 \\
\hline Diaspore & $\alpha-\mathrm{AlOOH}$ & 9 \\
\hline Goethite & $\mathrm{Fe}_{2} \mathrm{O}_{3} \cdot \mathrm{H}_{2} \mathrm{O}$ & 9 \\
\hline Perovskite & $\mathrm{CaTiO}_{3}$ & 4.5 \\
\hline Chamosite & $\left(\mathrm{Fe}^{2+}, \mathrm{Mg}\right)_{5} \mathrm{Al}\left(\mathrm{AlSi}_{3} \mathrm{O}_{10}\right)(\mathrm{OH})_{8}$ & 4 \\
\hline Calcite & $\mathrm{CaCO}_{3}$ & 4 \\
\hline Boehmite & $\gamma-\mathrm{AlOOH}$ & 3 \\
\hline Gibbsite & $\mathrm{Al}(\mathrm{OH})_{3}$ & 2 \\
\hline Rutile & $\mathrm{TiO}_{2}$ & 0.5 \\
\hline Anatase & $\mathrm{TiO}_{2}$ & 0.5 \\
\hline Sum & & 98.5 \\
\hline
\end{tabular}


From particle size distribution analysis, it was found that $50 \%$ of the particles were below $1.87 \mu \mathrm{m}$, while $90 \%$ were smaller than $42.87 \mu \mathrm{m}$.

\subsection{Ionic Liquid Characterization}

1-ethyl-3-methylimidazolium hydrogensulfate ([Emim] $\left.\left[\mathrm{HSO}_{4}\right]\right)$ is a Brønsted acidic ionic liquid whose molecular weight is $208.24 \mathrm{~g} / \mathrm{mol}$ and density $(\rho)$ at room temperature is $1367.9 \mathrm{~kg} / \mathrm{m}^{3}$. The molecular structure of the IL is shown in Figure 1.
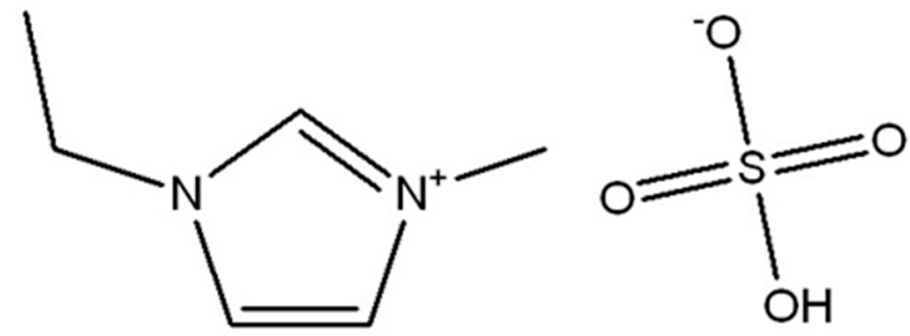

Figure 1. [Emim] $\left[\mathrm{HSO}_{4}\right]$ molecular structure.

Viscosity measurements (Figure 2) have revealed that even though [Emim] $\left[\mathrm{HSO}_{4}\right]$ is very viscous at room temperature $(1642 \mathrm{mPa} \cdot \mathrm{s})$, by increasing temperature its viscosity dramatically decreases, reaching $221 \mathrm{mPa} \cdot \mathrm{s}$ at $60{ }^{\circ} \mathrm{C}$ and $33 \mathrm{mPa} \cdot \mathrm{s}$ at $120^{\circ} \mathrm{C}$.

Midinfrared spectrum have shown bands $\left(\mathrm{cm}^{-1}\right)$ at $3452(\mathrm{OH}), 3151$ (aromatic/imidazole $\left.\mathrm{CH}\right)$, 3106 (imidazole ring), $2985(\mathrm{CH}), 2944(\mathrm{CH}), 2881\left(\left(\mathrm{CH}_{2}\right)_{\mathrm{n}}-\mathrm{CH}_{3}\right), 2583-2497$ (HOSO•••HOSO), 1636 $(\mathrm{OH}), 1572(\mathrm{C}=\mathrm{C}, \mathrm{C}=\mathrm{N}, \mathrm{C}-\mathrm{N}), 1454\left(\mathrm{CH}_{3}\right), 1431\left(\mathrm{~S}=\mathrm{O}_{2}\right), 1389\left(\mathrm{CH}_{3}\right), 1211\left(\mathrm{~S}=\mathrm{O}_{2}\right), 1160(\mathrm{~S}-\mathrm{O}$ attached to $\left.\mathrm{C}_{2} \mathrm{H}_{5}\right), 1089\left(\mathrm{HSO}_{4}{ }^{-}\right), 1023(\mathrm{C}-\mathrm{N}-\mathrm{C}), 960$ (O-S-O), 832 (imidazole ring), 757 (CH of imidazole ring) and $701(\mathrm{C}-\mathrm{H}-\mathrm{C}) .{ }^{1} \mathrm{H}$ NMR (500 MHz, DMSO) $\delta(\mathrm{ppm}): 1.36\left(\mathrm{t}, 3 \mathrm{H}, \mathrm{CH}_{3}\right), 3.85\left(\mathrm{~s}, 3 \mathrm{H}, \mathrm{CH}_{3}\right), 4.19(\mathrm{q}$, $\left.2 \mathrm{H}, \mathrm{CH}_{2}\right), 7.71(\mathrm{~s}, 1 \mathrm{H}, \mathrm{CH}=\mathrm{CH}), 7.78(\mathrm{~s}, 1 \mathrm{H}, \mathrm{CH}=\mathrm{CH}), 9.19$ (s, 1H, N-CH-N).

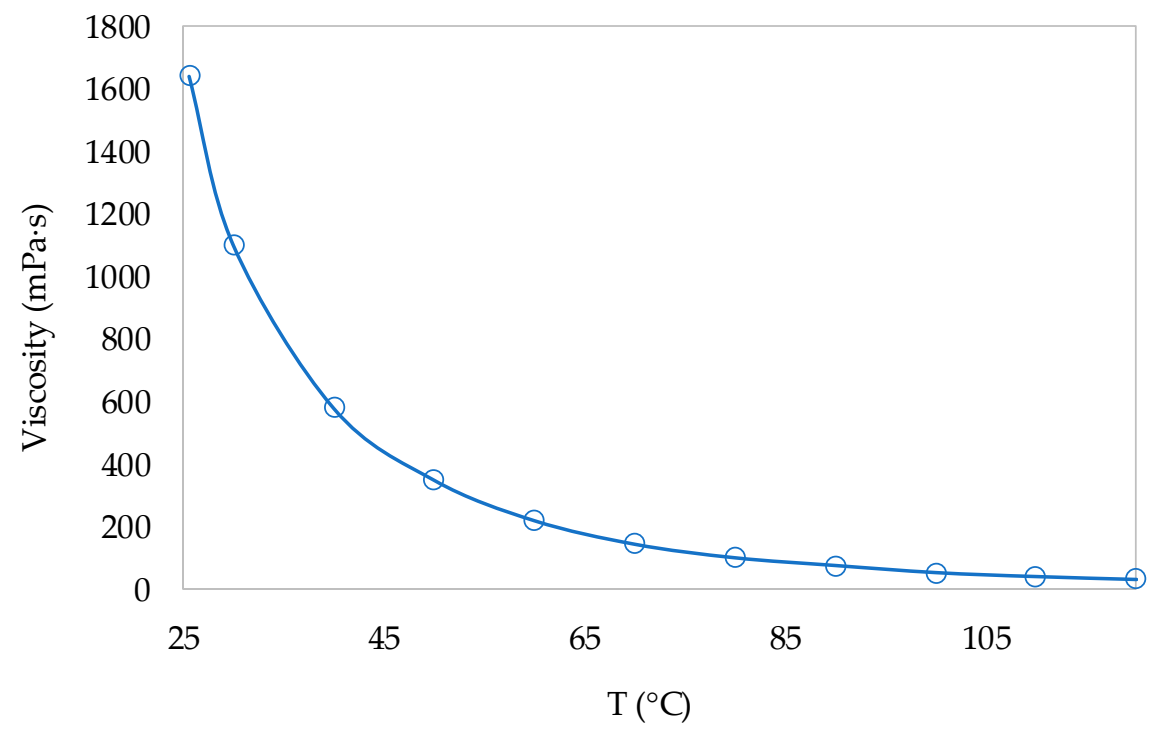

Figure 2. Viscosity measurements of $[\mathrm{Emim}]\left[\mathrm{HSO}_{4}\right]$ versus temperature.

Reaction Mechanism

To investigate the mechanism of the reaction that takes place, two monometallic solutions of $11 \mathrm{~g} / \mathrm{L}$ of $\mathrm{Sc}$ and $11 \mathrm{~g} / \mathrm{L}$ of $\mathrm{Al}$ were prepared, by dissolving $\mathrm{Sc}_{2} \mathrm{O}_{3}$ and $\mathrm{Al}_{2} \mathrm{O}_{3}$ in $\left[\right.$ Emim] $\left[\mathrm{HSO}_{4}\right]$.

The two monometallic solutions were then analyzed with ${ }^{1} \mathrm{H}$ and ${ }^{13} \mathrm{C}$ NMR. Assignment of ${ }^{1} \mathrm{H}$ and ${ }^{13} \mathrm{C}$ chemical shifts was based on the combined analyses of a series of ${ }^{1} \mathrm{H}-{ }^{1} \mathrm{H}$ and ${ }^{1} \mathrm{H}-{ }^{13} \mathrm{C}$ correlation experiments recorded using standard pulse sequences from the Bruker library. 
From the results (Appendix A, Figures A1 and A2), it could be concluded that there is no significant rearrangement in the carbon chain after the dissolution procedure in all three metal cases.

${ }^{1} \mathrm{H}$ and ${ }^{13} \mathrm{C}$ NMR spectra did not indicate any notable differences in the chemical shifts depending on the leached metal. The similar chemical shifts for the protons and the carbons localized in between the two nitrogen atoms indicate metal interaction through the anion of the IL.

There is not any steric effect of electron clouds changing of electrostatic interactions between ionic charges.

The results obtained from NMR analysis of two monometallic leachates have led to the following proposed reaction:

$$
\mathrm{Me}_{2} \mathrm{O}_{\mathrm{n}}+\mathrm{n}[\text { Emim }]\left[\mathrm{HSO}_{4}\right]=\mathrm{Me}_{2}\left(\mathrm{SO}_{4}\right)_{\mathrm{n}}+\mathrm{nOH}^{-}+\mathrm{n}[\mathrm{Emim}]^{+}
$$

where Me is the metal and $\mathrm{n}$ is the oxidation state of the metal.

\subsection{Leaching Process Optimization: Parameters Affecting the System}

In order to optimize the process, stirring rate, retention time, temperature, and pulp density were investigated. Each parameter was studied separately, keeping the others constant, and choosing the combination that gave the best results. In each case, $\mathrm{Ca}$ and $\mathrm{Si}$ in leachates were below the detection limit and $\mathrm{Ce}, \mathrm{Nd}, \mathrm{Y}$ and La recovery was lower than $1 \%$.

\subsubsection{Stirring Rate}

Initially, experiments were carried out by examining four different stirring rates, 100, 200, 400 and 600 revolutions per minute (rpm), while keeping constant all the other parameters at $150{ }^{\circ} \mathrm{C}, 5 \% \mathrm{w} / \mathrm{v}$ pulp density and $24 \mathrm{~h}$. Results are given in Figure 3.

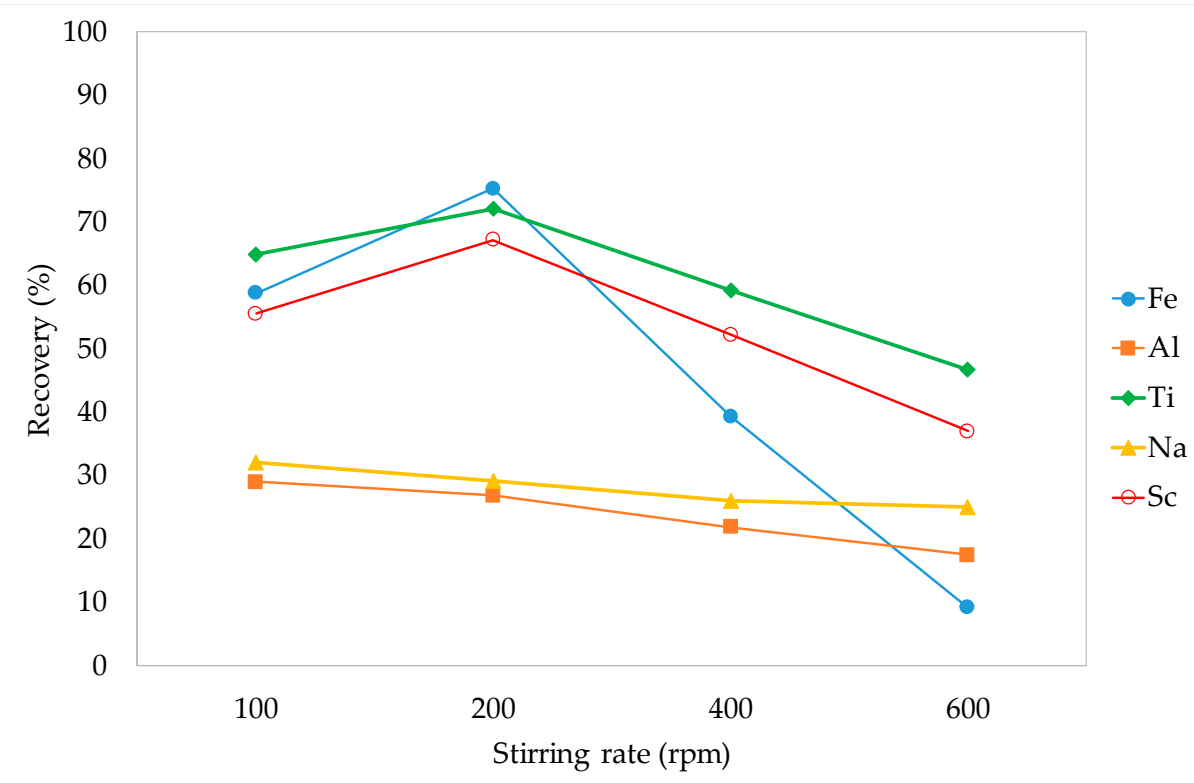

Figure 3. Investigation of the stirring rate effect on metals dissolution by leaching BR with $\left[\right.$ Emim] $\left[\mathrm{HSO}_{4}\right]$ at $150{ }^{\circ} \mathrm{C}, 5 \% \mathrm{w} / \mathrm{v}$ pulp density for $24 \mathrm{~h}$.

At these conditions, it is possible to observe an increase of $\mathrm{Fe}, \mathrm{Ti}$, and $\mathrm{Sc}$ extraction when the stirring rate increases from 100 to $200 \mathrm{rpm}$ (from $55 \%$ of Sc, $57 \%$ of $\mathrm{Fe}$, and $65 \%$ of Ti at $100 \mathrm{rpm}$ to $67 \%$ of $\mathrm{Sc}, 75 \%$ of $\mathrm{Fe}$ and $72 \%$ of $\mathrm{Ti}$ at $200 \mathrm{rpm}$ ). On the other hand, as the stirring rate increases from 200 to $600 \mathrm{rpm}, \mathrm{Fe}, \mathrm{Ti}$, and Sc extraction is observed to linearly decrease (from $67 \%$ of Sc, $75 \%$ of $\mathrm{Fe}$, and $72 \%$ of $\mathrm{Ti}$ at $200 \mathrm{rpm}$ to $37 \%$ of Sc, $46 \%$ of $\mathrm{Ti}$, and only $9 \%$ for Fe at $600 \mathrm{rpm}$ ). Na and Al recovery were 
slightly affected by the stirring rate as they remained almost stable in a range of $17-32 \%$ of recovery. This effect of stirring rate on metal recovery is typical in hydrometallurgy. Under low stirring rates, a thick boundary layer was developed on the surface of the solid particles, making the diffusion of chemical species from and to the solid particles surface inefficient. Therefore, at stirring rates lower than $200 \mathrm{rpm}$, the leaching process is slowed down and metal recovery decreases, as it is seen in Figure 3. At stirring rates higher than $200 \mathrm{rpm}$, the thickness of the boundary layer is substantially decreased, but the high convective mass transfer of reactants from the surface of the particles, makes the surface reactions again inefficient and thus the recovery yields are diminishing, as it is seen in Figure 3. Therefore, a compromise is always found under intermediate stirring rates which, for this system, is around $200 \mathrm{rpm}$. At this stirring rate, $\mathrm{Fe}, \mathrm{Ti}$, and Sc have the highest recovery yields $(75 \%$, $72 \%$ and $67 \%$ respectively).

\subsubsection{Kinetic Studies}

Several sets of kinetic have been performed at $200 \mathrm{rpm}$ stirring rate, $5 \% w / v$ pulp density, analyzing the behavior of the system at three different temperatures: 150,175 , and $200{ }^{\circ} \mathrm{C}$.

In Figure 4 it is observed that at low temperature $\left(150^{\circ} \mathrm{C}\right)$, all metals show the same trend in the first twelve hours; an initial metal dissolution occurred in the first six hours, whilst in the following six hours, metals dissolution is decreased, reaching their lowest concentration at $12 \mathrm{~h}$ retention time. This unusual behavior can be attributed to the precipitation of $\mathrm{Ca}$ as $\mathrm{CaSO}_{4}$ that massively occurs within the first $6 \mathrm{~h}$ (Appendix A, Figure A3), while Fe dissolution is low. In the latter $6 \mathrm{~h}$, adsorption phenomena were more important and faster than dissolution and, being in contact with anhydrite, metals are removed from the leachates, attaining the minimum at $12 \mathrm{~h}$. Then, metals continue their dissolution and as the anhydrite precipitation has been completed they are gradually desorbed, increasing their concentration in solution and reaching the equilibrium at $24 \mathrm{~h}$ retention time, with the exception of iron that continues to be dissolved but at a substantially lower rate.

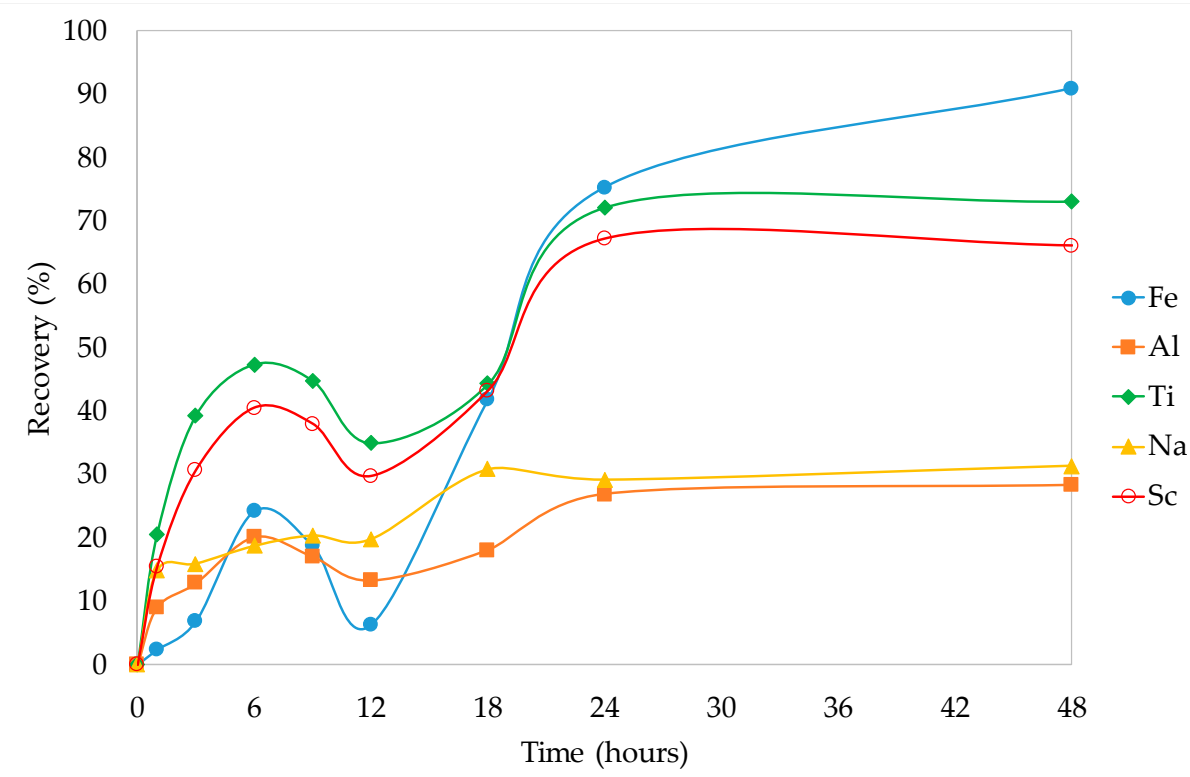

Figure 4. Kinetic curves for metals dissolution by leaching BR with [Emim] $\left[\mathrm{HSO}_{4}\right]$ at 1, 3, 6, 12, 18, 24 and $48 \mathrm{~h}, 200 \mathrm{rpm}, 150{ }^{\circ} \mathrm{C}$ and $5 \% \mathrm{w} / v$ pulp density.

Kinetic studies have been carried out at $175^{\circ} \mathrm{C}$ (Figure 5), in this case the unusual dissolution phenomenon observed at $150{ }^{\circ} \mathrm{C}$ was not seen and the plateau has been reached faster, after $12 \mathrm{~h}$, achieving $90 \%$ of $\mathrm{Fe}, 70 \%$ of $\mathrm{Ti}$ and $\mathrm{Sc}$ dissolution and again moderate $\mathrm{Al}$ and $\mathrm{Na}$ recovery $(30 \%)$. After $1 \mathrm{~h}$, more than $35 \%$ of Sc has been dissolved, this, as mentioned, is due to the fact that goethite 
is totally dissolved and hematite starts to be leached as well. The equilibrium has been reached at $70 \%$ of Sc and $90 \%$ of Fe recovery, which is in agreement with Vind et al. studies, as the main mineralogical Sc containing phases in bauxite residue are hematite and goethite (55\% and $25 \%$ on average, respectively) [38].

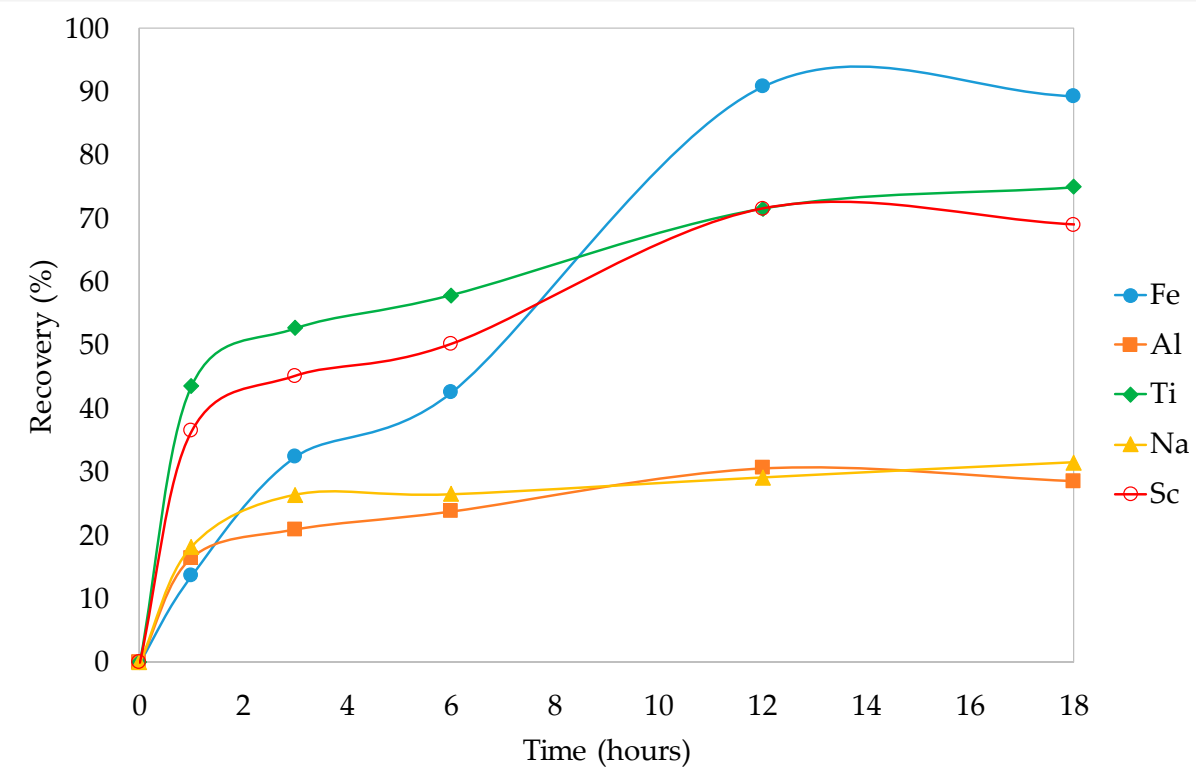

Figure 5. Kinetic curves for metals dissolution by leaching BR with [Emim] $\left[\mathrm{HSO}_{4}\right]$ at 1, 3, 6, 12, and $18 \mathrm{~h}, 200 \mathrm{rpm}, 175^{\circ} \mathrm{C}$ and $5 \% \mathrm{w} / \mathrm{v}$ pulp density.

At $200{ }^{\circ} \mathrm{C}$ (Figure 6), Fe, Ti and Sc are considerably leached even after $1 \mathrm{~h}$ (60-74\%). The maximum extraction of these metals has been reached after $12 \mathrm{~h}$, where Fe was almost totally dissolved, Ti recovery was over $90 \%$ and Sc reached nearly $80 \%$. Al and Na dissolution remained stable along the kinetic curve in a range of $30-40 \%$.

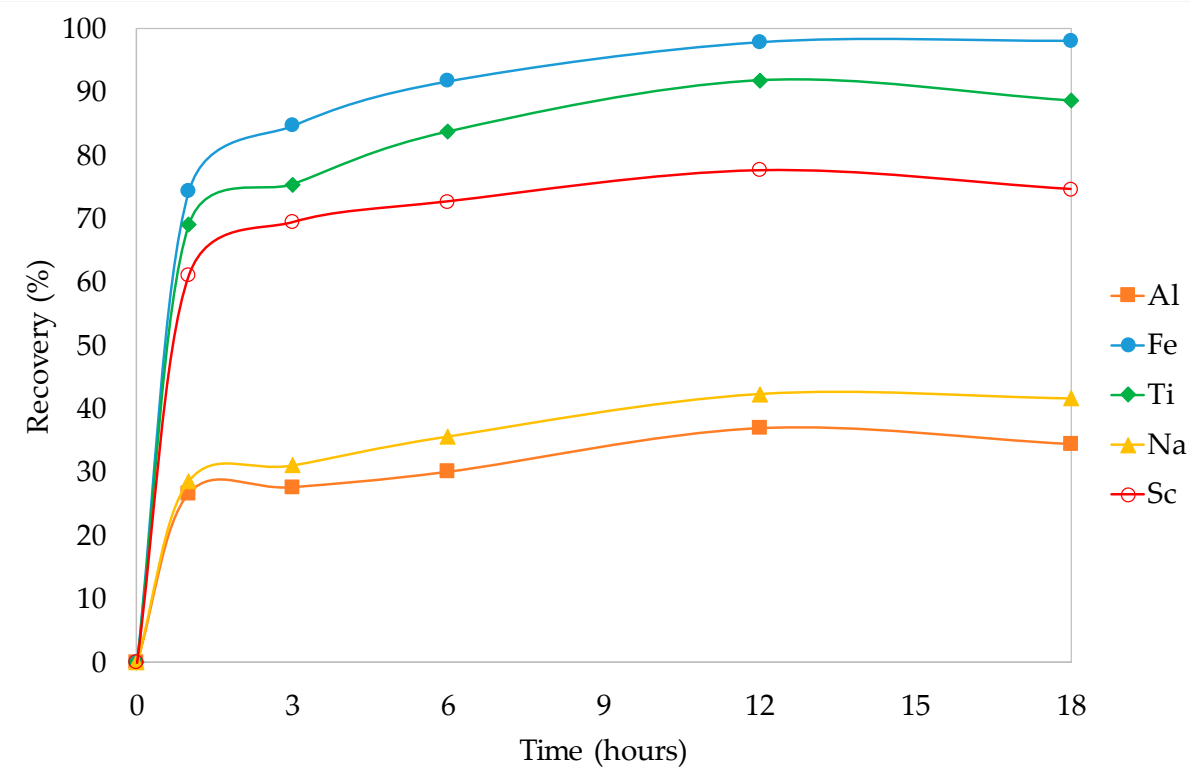

Figure 6. Kinetic curves for metals dissolution by leaching BR with [Emim] $\left[\mathrm{HSO}_{4}\right]$ at 1, 3, 6, 12, and $18 \mathrm{~h}, 200 \mathrm{rpm}, 200^{\circ} \mathrm{C}$, and $5 \% \mathrm{w} / v$ pulp density. 
Extraction of Sc at these high recovery yields (nearly 80\%), when Fe was also almost totally dissolved, again confirms that Sc was found to be hosted mainly in hematite and goethite mineralogical phases in bauxite residue [38], as already mentioned. It was hypothesized before that in the same experimental setup as given here, the unrecovered proportion of Sc (about $20 \%$ ) may be associated mainly with the chemically durable zirconium orthosilicate $\left(\mathrm{ZrSiO}_{4}\right)$, that contains around $10 \%$ of the total Sc in bauxite residue, but also with other undissolved (or partially dissolved) phases as boehmite, diaspore, and titanium-containing phases, which have been determined to be carriers of Sc in Greek BR [38].

\subsubsection{Pulp Density}

Four experiments have been conducted to investigate the effect of pulp density on the system, at $2.5 \%, 5 \%, 10 \%$, and $14.3 \% w / v$ pulp density, under constant temperature, time and stirring rate $\left(200{ }^{\circ} \mathrm{C}, 12 \mathrm{~h}\right.$, and $\left.200 \mathrm{rpm}\right)$. Results are shown in Figure 7.

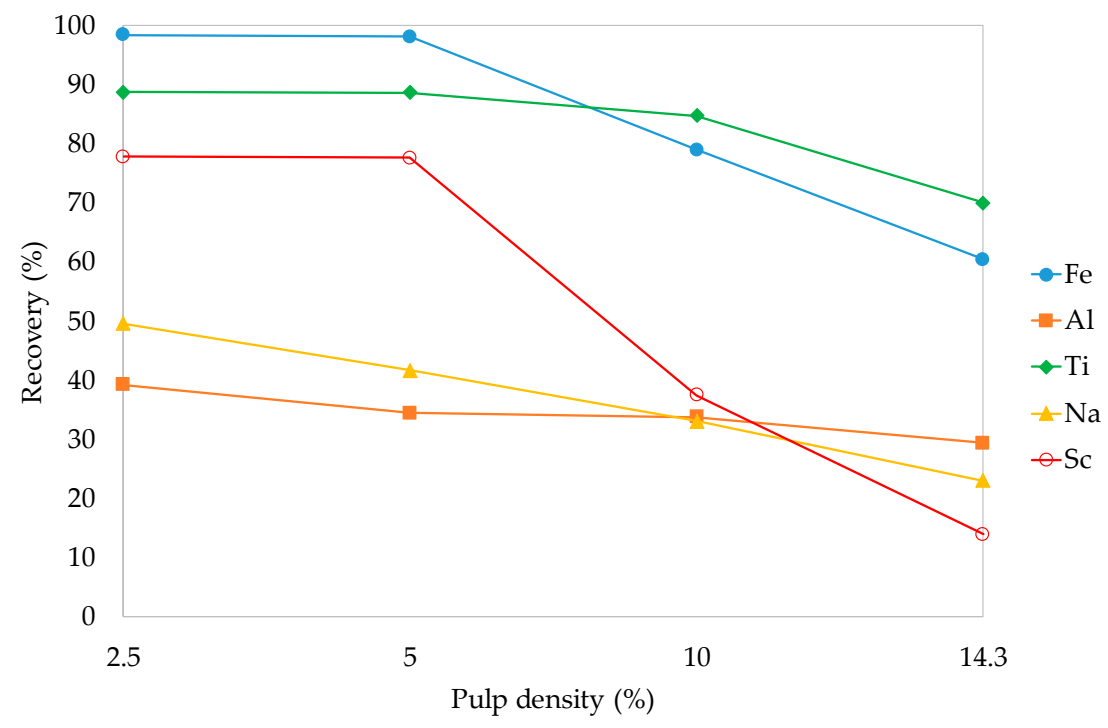

Figure 7. Study on the system behavior for metals dissolution by changing pulp density when leaching BR with $[$ Emim $]\left[\mathrm{HSO}_{4}\right]$ at $12 \mathrm{~h}, 200 \mathrm{rpm}, 200{ }^{\circ} \mathrm{C}$.

$\mathrm{Fe}, \mathrm{Ti}$, and Sc present constant recovery in the area of $2.5-5 \% w / v$ pulp density (almost total dissolution for $\mathrm{Fe}, 88 \%$ for $\mathrm{Ti}$, and $78 \%$ for Sc). This behavior can be explained by the extremely high ionic liquid excess and the relatively low viscosity of the system due to the low concentration of dissolved metals. By increasing pulp density, the ionic liquid excess decreases and viscosity substantially rises, due to the increase of the number of suspended BR particles as well as the dissolved metal concentrations affecting the ions mobility phenomena and the thickness of the boundary layer. This results in a sharp and linear decreasing recovery, reaching the minimum at $14.3 \% w / v(60 \%$ of $\mathrm{Fe}$, $70 \% \mathrm{Ti}$, and $14 \%$ of Sc). Experiments at pulp density higher than $14.3 \% w / v$ were not carried out due to the high viscosity, which prevented filtration and caused serious problems during the leaching process.

\subsection{Characterization of the Solid Residue after Leaching}

The solid residue collected after leaching bauxite residue at optimum conditions $\left(200 \mathrm{rpm}, 200{ }^{\circ} \mathrm{C}\right.$, $12 \mathrm{~h}$ and $5 \% \mathrm{w} / v$ pulp density) was characterized via fusion method, XRD, SEM, and TEM analyses. The resulting residue was found to be $48 \%$ of the weight of the initial BR mass.

As it can be seen from chemical analysis shown in Table 3, solid residue after leaching is high in aluminum, calcium, and silicon, while it is depleted in iron and titanium. REEs remain in the solid residue (with the exception of scandium) and can be leached afterwards. 
Table 3. Chemical analysis of the residue after leaching BR at optimum conditions.

\begin{tabular}{ccccccccccc}
\hline Metal Oxide & $\mathrm{Fe}_{2} \mathrm{O}_{3}$ & $\mathrm{Al}_{2} \mathrm{O}_{3}$ & $\mathrm{SiO}_{2}$ & $\mathrm{TiO}_{2}$ & $\mathrm{CaO}$ & $\mathrm{Na}_{2} \mathrm{O}$ & $\mathrm{REO}$ & $\mathrm{SO}_{3}$ & LOI & Others \\
\hline wt. $\%$ & 3.71 & 27.44 & 14.51 & 1.46 & 24.73 & 2.75 & 0.19 & 18.69 & 6.00 & 0.52 \\
\hline
\end{tabular}

From the comparison of the XRD spectra of bauxite residue and residue generated after leaching (Appendix A, Figure A4), it is possible to observe that peaks attributed to hematite, goethite, calcium aluminum iron silicate hydroxide, gibbsite, and perovskite, which are present in bauxite residue, disappear after leaching. Aluminum phases like diaspore and boehmite remain relatively intact after leaching, as well as cancrinite, chamosite, and calcite. On the other hand, a new mineralogical phase calcium sulfate anhydrite (causing the consumption of about $2 \mathrm{wt} . \%$ of the IL), which was formed due to the interaction between calcium and the anion of the ionic liquid, is created during leaching. The above observations explain well the behavior of $\mathrm{Al}$ and $\mathrm{Na}$ during leaching as their main minerals in BR such as diaspore, boehmite and cancrinite remain insoluble, leading to low to moderate recoveries. On the other hand, Fe and Ti bearing minerals were depleted in leaching residue thus confirming their observed high recoveries. Regarding Ca leaching, phases like calcium aluminum iron silicate hydroxide are substantially soluble, while phases such as cancrinite and chamosite resist dissolution. Calcite is partially dissolved in IL solution and in the presence of $\mathrm{HSO}_{4}{ }^{-}$anions, undertakes a transition to anhydrite, which is a secondary precipitated phase during the leaching process.

SEM-EDS analysis of the solid residue after leaching confirmed the findings of chemical and XRD analyses (Figure 8). The matrix, which is mainly composed of $\mathrm{Al}, \mathrm{Ca}$, and Na silicates, surrounds phases transitioning from $\mathrm{CaCO}_{3}$ to $\mathrm{CaSO}_{4}$.

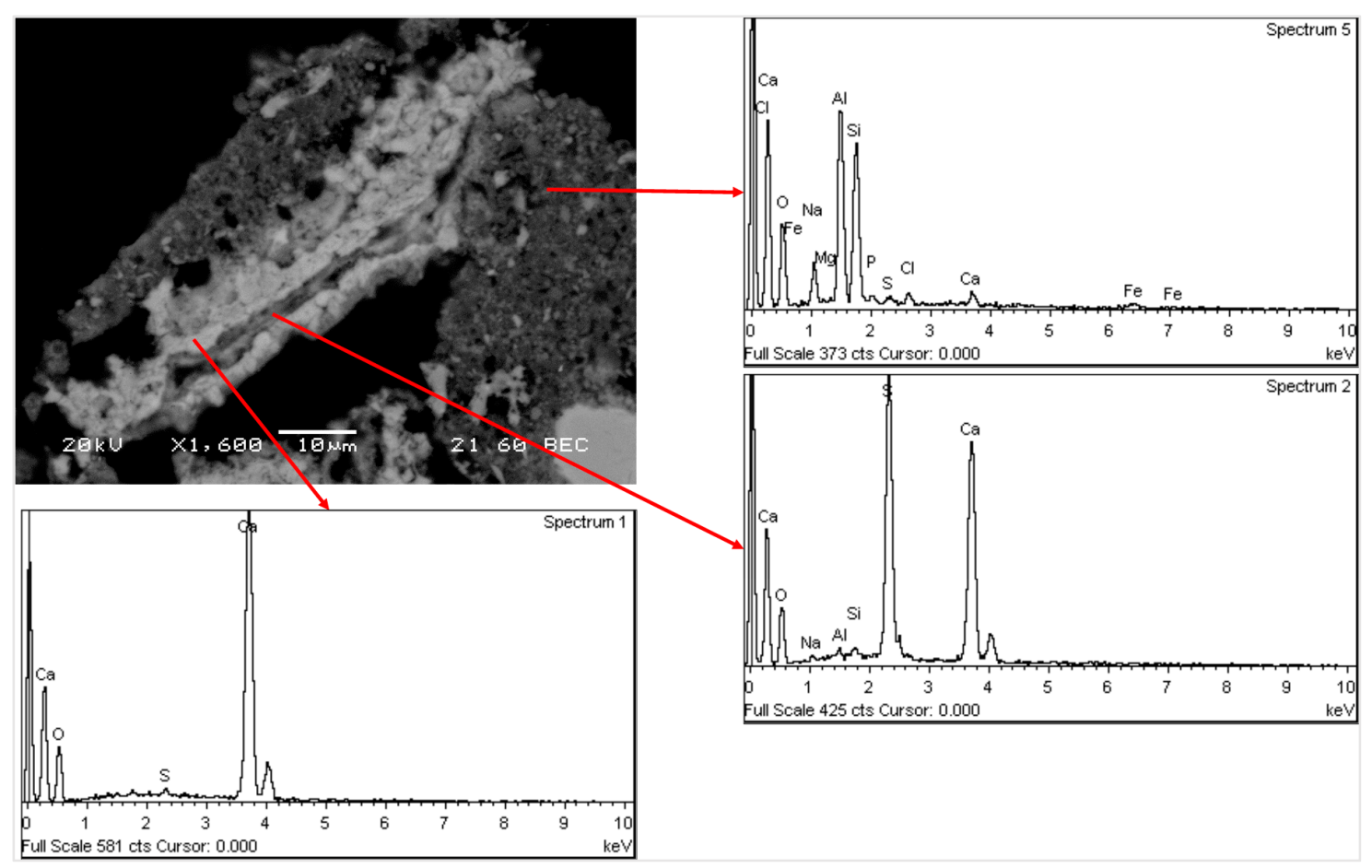

Figure 8. Scanning electron microscope (SEM image of the matrix of the residue after leaching).

\subsection{REEs in the Solid Residue}

Small REEs-containing particles (about $10 \mu \mathrm{m}$ ) were detected in SEM-EDS, in particular $\mathrm{YPO}_{4}$ particles including heavy rare earths like gadolinium and dysprosium (Figure 9 left). This is consistent with Vind et al. studies of raw bauxite residue [39] where the presence of heavy rare earth phosphates with the major constituent being yttrium and containing other heavy REEs like 
gadolinium, dysprosium, and erbium is reported. This is an indication that these grains endure the $[$ Emim $]\left[\mathrm{HSO}_{4}\right]$ leaching process without being subjected to any dissolution and thus explaining negligible heavy REEs recoveries.
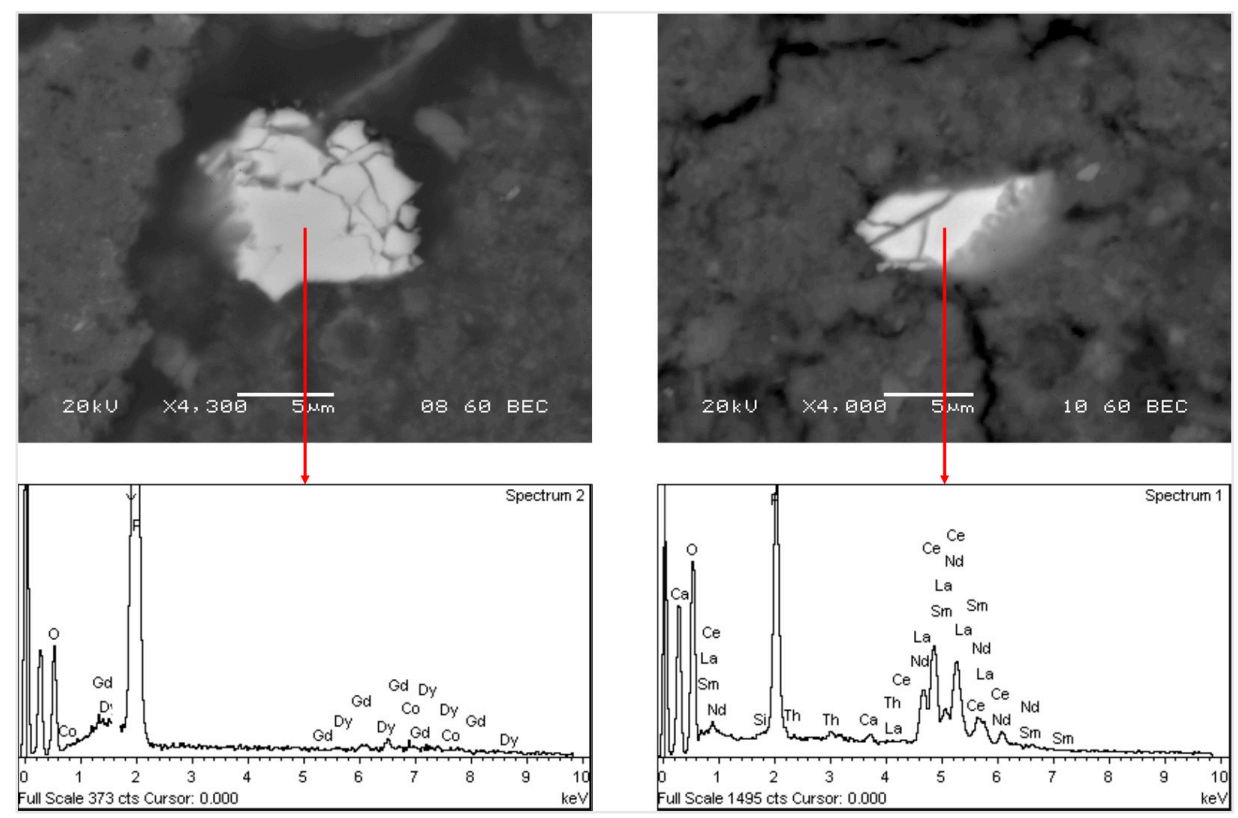

Figure 9. SEM image of a $\mathrm{YPO}_{4}$ particle (left) and a $\mathrm{CePO}_{4}$ particle (right).

Small mixed calcium-cerium phosphate particles were also identified; in this case, grains included light rare earths like neodymium, lanthanum, and samarium (Figure 9 right). Vind et al. reported the presence of light rare earths as calcium-containing phosphate phases in bauxite residue [39]. In the case of the solid residue after leaching, grains containing light REEs (LREEs) phosphates are also present. This may indicate a partial dissolution of calcium from the mixed Ca-LREEs phases, leaving behind smaller phosphate particles which are beneficiated in LREEs. This was also implied by TEM analysis, detecting very fine $(<500 \mathrm{~nm})$ particles of Al-containing $\mathrm{CePO}_{4}$ (Figure 10).

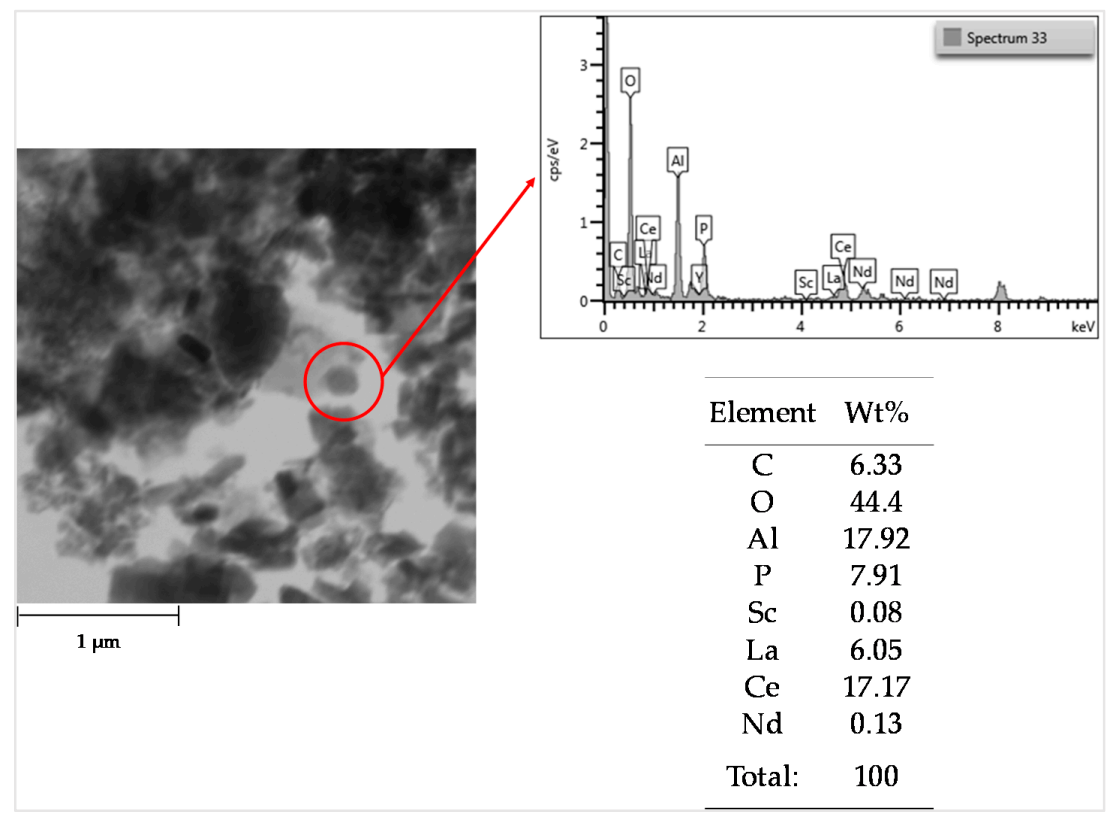

Figure 10. TEM image of a $\mathrm{CePO}_{4}, \mathrm{Al}$ containing, particle. 


\section{Conclusions}

In this study, Brønsted acidic ionic liquid 1-ethyl-3-methylimidazolium hydrogensulfate was used to directly leach bauxite residue. Experiments were carried out in a closed mini reactor, equipped with a condenser and a temperature controller. Stirring rate, time, temperature and pulp density were thoroughly examined to find the optimum conditions for Sc (nearly 80\%) and Fe (almost totally dissolved) high recovery yields. This outcome confirms that Sc is mainly hosted in hematite and goethite mineralogical phases (55\% and $25 \%$, respectively) in bauxite residue, in accordance to the work of Vind et al. [38]. The undissolved Sc content might be attributed to $\mathrm{ZrSiO}_{4}$, containing around $10 \%$ of the total Sc in bauxite residue, but also to other phases, such as boehmite, diaspore, and titanium-containing phases that host Sc in Greek bauxite residue [38].

At the optimum conditions, $90 \%$ of $\mathrm{Ti}$ was dissolved, while $\mathrm{Al}$ and $\mathrm{Na}$ were partially extracted (in a range of 30-40\%). Si and REEs dissolutions were found to be negligible, whereas Ca was partially dissolved and precipitated as $\mathrm{CaSO}_{4}$ consuming about $2 \mathrm{wt} . \%$ of the ionic liquid.

Solid residue after leaching was fully characterized and found to be rich in $\mathrm{Al}, \mathrm{Ca}$, and $\mathrm{Si}$, with the main minerals present being anhydrite, diaspore, and cancrinite; it could be further treated to extract REEs. SEM and TEM analyses of the solid residues provided explanations for the destiny of REEs, which remain undissolved enduring the leaching process.

It can be concluded that [Emim] $\left[\mathrm{HSO}_{4}\right]$ ionic liquid is a good leaching agent for dissolving metals from bauxite residue and, since it is not selective against iron, high recovery yields of Sc can be achieved, reaching up to $80 \%$ of extraction.

Author Contributions: C.B. and D.P. conceived and designed the experiments; C.B. performed the experiments; A.P. performed NMR analysis and analyzed the spectra; A.A. performed chemical analyses; J.V. and C.B. performed the SEM-EDS analysis and analyzed the data; P.T. performed TEM analysis; C.B. analyzed the data and wrote the paper; D.P. contributed to the analysis of the data and the writing of the paper.

Acknowledgments: The research leading to these results has received funding from the European Community's Horizon 2020 Program (H2020/2014-2019) under Grant Agreement no. 636876 (MSCA-ETN REDMUD).

Conflicts of Interest: The authors declare no conflict of interest. The funding sponsors had no role in the design of the study; in the collection, analyses, or interpretation of data; in the writing of the manuscript, and in the decision to publish the results. 


\section{Appendix A}

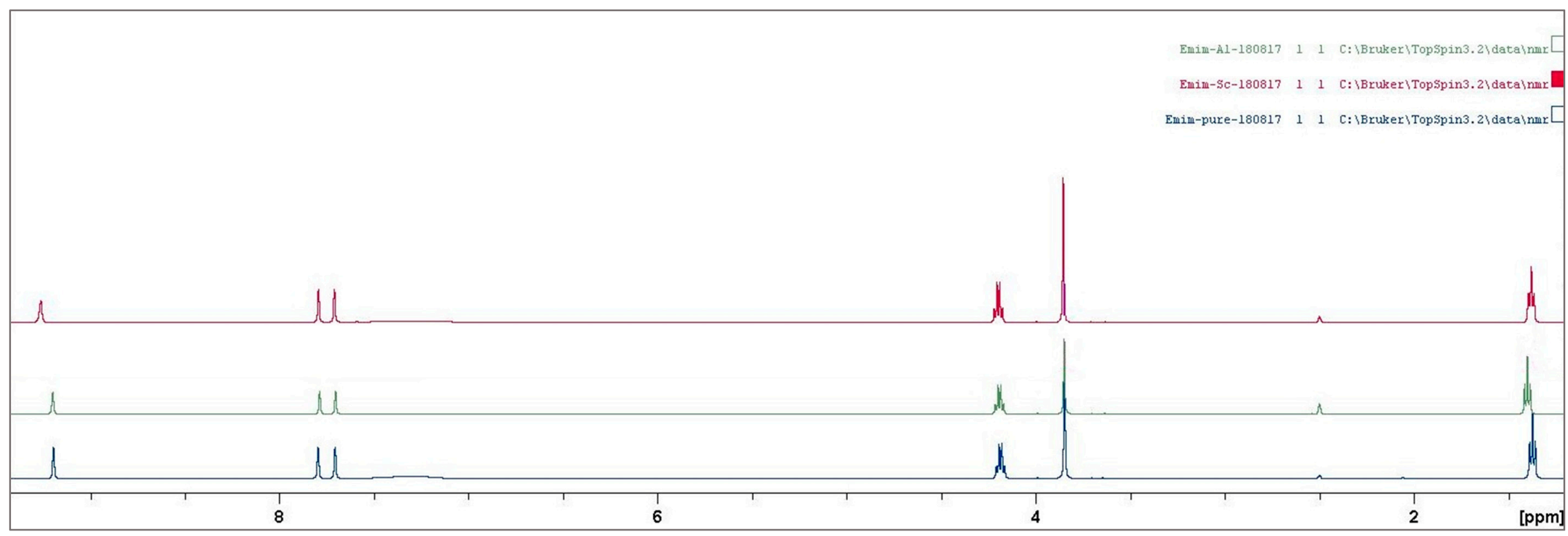

Figure A1. ${ }^{1} \mathrm{H}$ Nuclear Magnetic Resonance (NMR) comparison between [Emim] $\left[\mathrm{HSO}_{4}\right]$ (blue), [Emim] $\left[\mathrm{HSO}_{4}\right]$ after leaching $\mathrm{Al}_{2} \mathrm{O}_{3}$ (green), [Emim] $\left[\mathrm{HSO}{ }_{4}\right]$ after leaching $\mathrm{Sc}_{2} \mathrm{O}_{3}$ (red) 


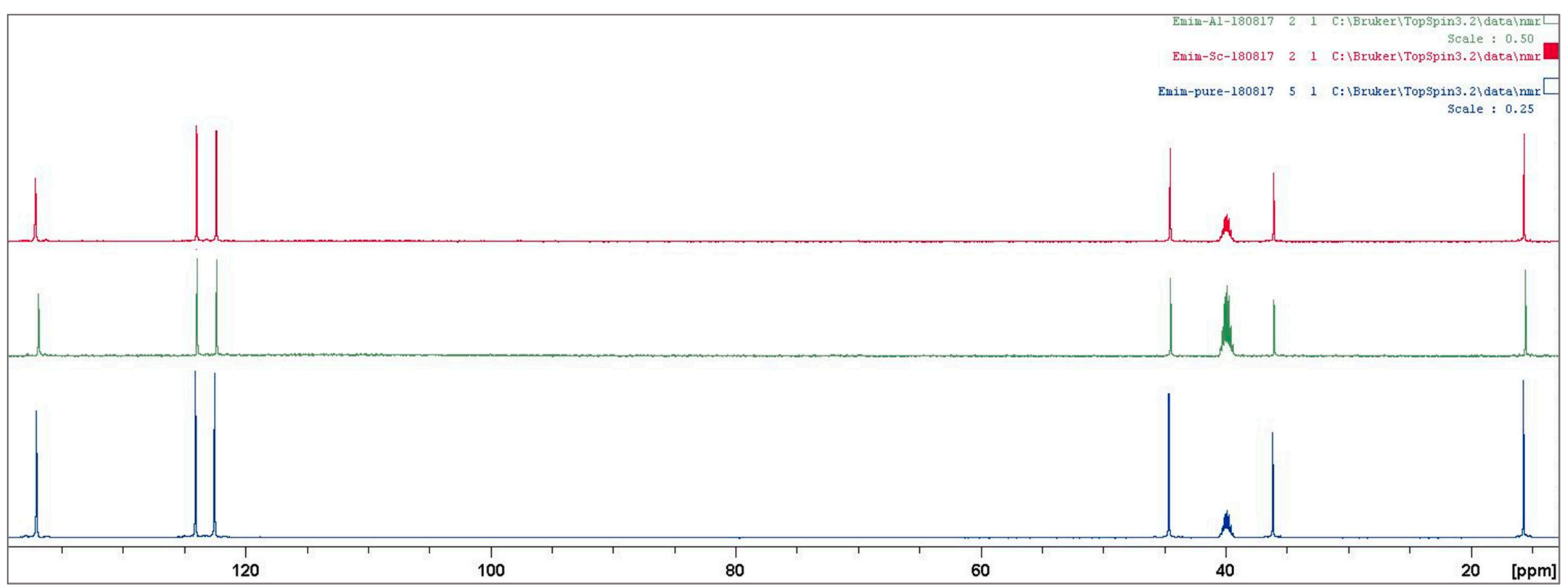

Figure A2. ${ }^{13} \mathrm{C}$ NMR comparison between [Emim] $\left[\mathrm{HSO}_{4}\right]$ (blue), [Emim] $\left[\mathrm{HSO}_{4}\right]$ after leaching $\mathrm{Al}_{2} \mathrm{O}_{3}$ (green), [Emim] $\left[\mathrm{HSO}_{4}\right]$ after leaching $\mathrm{Sc}_{2} \mathrm{O}_{3}$ (red) 

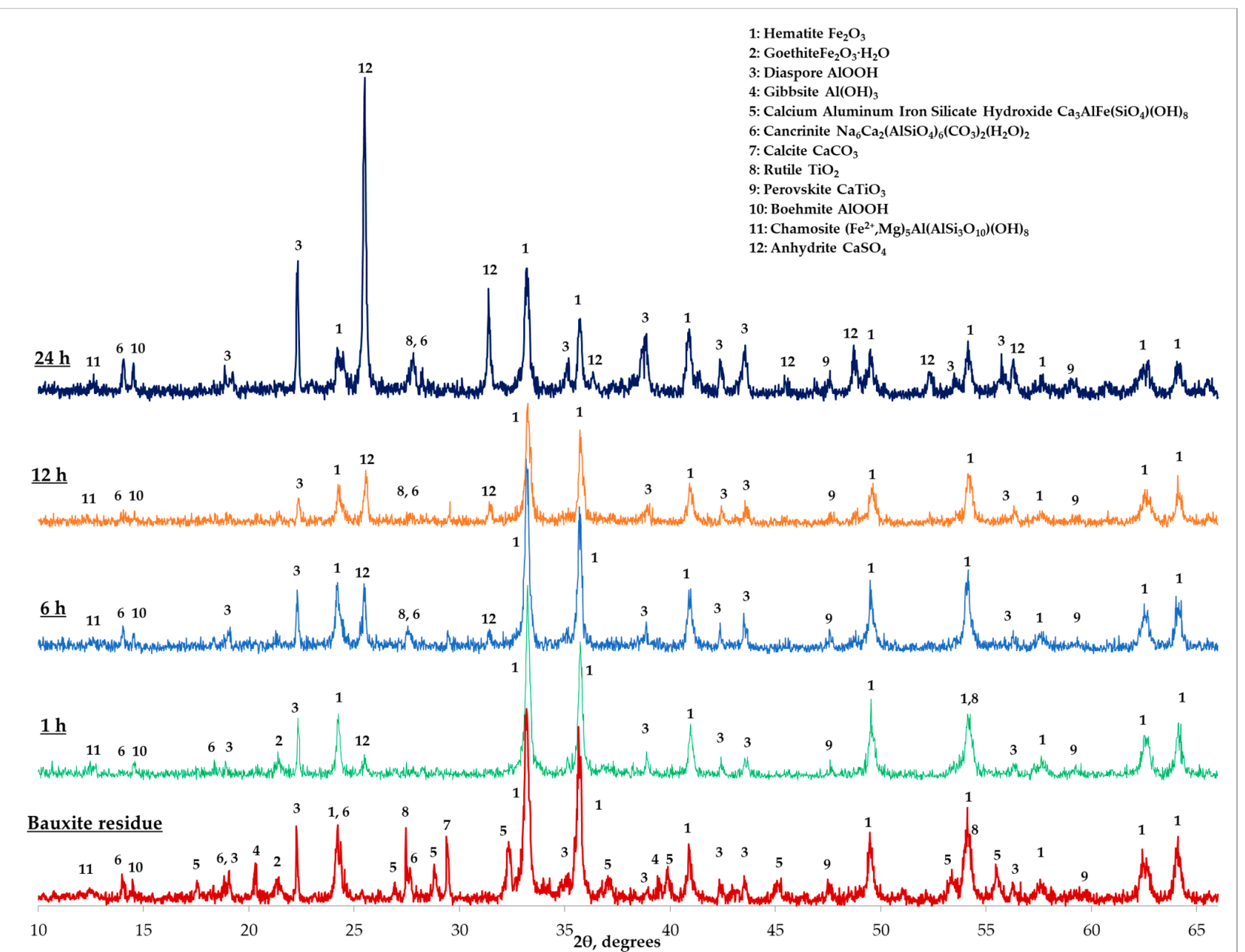

Figure A3. Comparison between X-ray powder diffractometer (XRD) of bauxite residue and solid residue after leaching bauxite residue at $150{ }^{\circ} \mathrm{C}, 200 \mathrm{rpm}, 5 \% w / v$ pulp density for 1, 6, 12, and $24 \mathrm{~h}$. 


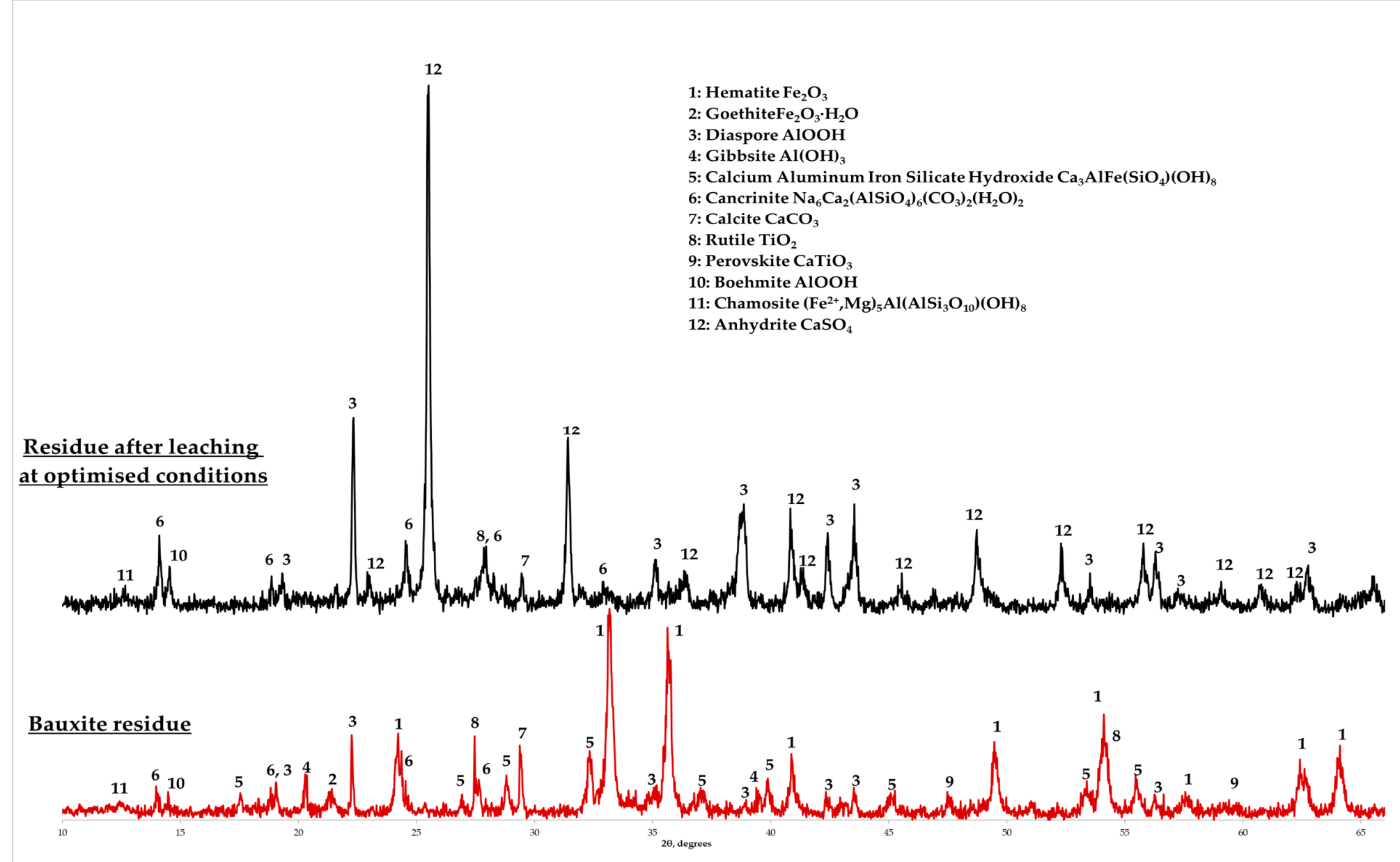

Figure A4. Comparison of the XRD spectra of bauxite residue and solid residue after leaching at optimum conditions. 


\section{References}

1. Evans, K. The History, Challenges, and New Developments in the Management and Use of Bauxite Residue. J. Sustain. Metall. 2016, 2, 316-331. [CrossRef]

2. Zhang, R.; Zheng, S.; Ma, S.; Zhang, Y. Recovery of Alumina and Alkali in Bayer Red Mud by the Formation of Andradite-Grossular Hydrogarnet in Hydrothermal Process. J. Hazard. Mater. 2011, 189, 827-835. [CrossRef] [PubMed]

3. Klauber, C.; Gräfe, M.; Power, G. Bauxite Residue Issues: II. Options for Residue Utilization. Hydrometallurgy 2011, 108, 11-32. [CrossRef]

4. Gräfe, M.; Power, G.; Klauber, C. Bauxite Residue Issues: III. Alkalinity and Associated Chemistry. Hydrometallurgy 2011, 108, 60-79. [CrossRef]

5. Liu, Y.; Naidu, R. Hidden Values in Bauxite Residue (Red Mud): Recovery of Metals. Waste Manag. 2014, 34 , 2662-2673. [CrossRef] [PubMed]

6. Ochsenkühn-Petropulu, M.; Lyberopulu, T.; Parissakis, G. Direct Determination of Landthanides, Yttrium and Scandium in Bauxites and Red Mud from Alumina Production. Anal. Chim. Acta 1994, 296, 305-313. [CrossRef]

7. Vind, J.; Alexandri, A.; Vassiliadou, V.; Panias, D. Distribution of Selected Trace Elements in the Bayer Process. Metals (Basel) 2018, 8, 327. [CrossRef]

8. Rudnick, R.L.; Gao, S. Composition of the Continental Crust. In Treatise on Geochemistry; Elsevier: Amsterdam, The Netherlands, 2003; pp. 1-64.

9. Gambogi, J. Mineral Commodity Summaries, Scandium; U.S. Geological Survey: Reston, VA, USA, 2017; pp. 146-147.

10. Balomenos, E.; Davris, P.; Pontikes, Y.; Panias, D. Mud2Metal: Lessons Learned on the Path for Complete Utilization of Bauxite Residue Through Industrial Symbiosis. J. Sustain. Metall. 2017, 3, 551-560. [CrossRef]

11. Deloitte Sustainability; British Geological Survey; Bureau de Recherches Géologiques et Minières; TNO. Study on the Review of the List of Critical Raw Materials; EU Law and Publications: Luxembourg, 2017; ISBN 978-92-79-47937-3.

12. Borra, C.R.; Blanpain, B.; Pontikes, Y.; Binnemans, K.; Van Gerven, T. Recovery of Rare Earths and Other Valuable Metals From Bauxite Residue (Red Mud): A Review. J. Sustain. Metall. 2016, 2, 365-386. [CrossRef]

13. Ochsenkühn-Petropulu, M.; Lyberopulu, T.; Parissakis, G. Selective Separation and Determination of Scandium from Yttrium and Lanthanides in Red Mud by a Combined Ion Exchange/Solvent Extraction Method. Anal. Chim. Acta 1995, 315, 231-237. [CrossRef]

14. Binnemans, K.; Jones, P.T.; Blanpain, B.; Van Gerven, T.; Pontikes, Y. Towards Zero-Waste Valorisation of Rare-Earth-Containing Industrial Process Residues: A Critical Review. J. Clean. Prod. 2015, 99, 17-38. [CrossRef]

15. Bonomi, C.; Cardenia, C.; Yin, P.T.W.; Panias, D. Review of Technologies in the Recovery of Iron, Aluminium, Titanium and Rare Earth Elements from Bauxite Residue (Red Mud). In Proceedings of the International Symposium on Enhanced Landfill Mining, Lisboa, Portugal, 8-10 February 2016; pp. 259-276.

16. Alkan, G.; Schier, C.; Gronen, L.; Stopic, S.; Friedrich, B. A Mineralogical Assessment on Residues after Acidic Leaching of Bauxite Residue (Red Mud) for Titanium Recovery. Metals 2017, 7, 458. [CrossRef]

17. Agatzini-Leonardou, S.; Oustadakis, P.; Tsakiridis, P.E.; Markopoulos, C. Titanium Leaching from Red Mud by Diluted Sulfuric Acid at Atmospheric Pressure. J. Hazard. Mater. 2008, 157, 579-586. [CrossRef] [PubMed]

18. Alkan, G.; Yagmurlu, B.; Cakmakoglu, S.; Hertel, T.; Kaya, Ş.; Gronen, L.; Stopic, S.; Friedrich, B. Novel Approach for Enhanced Scandium and Titanium Leaching Efficiency from Bauxite Residue with Suppressed Silica Gel Formation. Sci. Rep. 2018, 8, 5676. [CrossRef] [PubMed]

19. Liu, Z.; Li, H. Metallurgical Process for Valuable Elements Recovery from Red Mud-A Review. Hydrometallurgy 2015, 155, 29-43. [CrossRef]

20. Ochsenkühn-Petropoulou, M.T.; Hatzilyberis, K.S.; Mendrinos, L.N.; Salmas, C.E. Pilot-Plant Investigation of the Leaching Process for the Recovery of Scandium from Red Mud. Ind. Eng. Chem. Res. 2002, 41, 5794-5801. [CrossRef]

21. Ochsenkühn-Petropulu, M.; Lyberopulu, T.; Ochsenkühn, K.M.; Parissakis, G. Recovery of Lanthanides and Yttrium from Red Mud by Selective Leaching. Anal. Chim. Acta 1996, 319, 249-254. [CrossRef] 
22. Borra, C.R.; Blanpain, B.; Pontikes, Y.; Binnemans, K.; Van Gerven, T. Smelting of Bauxite Residue (Red Mud) in View of Iron and Selective Rare Earths Recovery. J. Sustain. Metall. 2016, 2, 28-37. [CrossRef]

23. Borra, C.R.; Pontikes, Y.; Binnemans, K.; Van Gerven, T. Leaching of Rare Earths from Bauxite Residue (Red Mud). Miner. Eng. 2015, 76, 20-27. [CrossRef]

24. Bonomi, C.; Davris, P.; Balomenos, E.; Giannopoulou, I.; Panias, D. Ionometallurgical Leaching Process of Bauxite Residue: A Comparison between Hydrophilic and Hydrophobic Ionic Liquids. In Proceedings of the 35th International ICSOBA Conference, Hamburg, Germany, 2-5 October 2017; pp. 557-564.

25. Abbott, A.P.; Frisch, G.; Hartley, J.; Ryder, K.S. Processing of Metals and Metal Oxides Using Ionic Liquids. Green Chem. 2011, 13, 471. [CrossRef]

26. Vander Hoogerstraete, T.; Onghena, B.; Binnemans, K. Homogeneous Liquid-Liquid Extraction of Rare Earths with the Betaine-Betainium Bis(Trifluoromethylsulfonyl)Imide Ionic Liquid System. Int. J. Mol. Sci. 2013, 14, 21353-21377. [CrossRef] [PubMed]

27. Wellens, S.; Thijs, B.; Möller, C.; Binnemans, K. Separation of Cobalt and Nickel by Solvent Extraction with Two Mutually Immiscible Ionic Liquids. Phys. Chem. Chem. Phys. 2013, 15, 9663. [CrossRef] [PubMed]

28. Wasserscheid, P.; Keim, W. Ionic Liquids-New "Solutions" for Transition Metal Catalysis. Angew. Chemie 2000, 39, 3772-3789. [CrossRef]

29. Welton, T. Room-Temperature Ionic Liquids. Solvents for Synthesis and Catalysis. Chem. Rev. 1999, 99, 2071-2084. [CrossRef] [PubMed]

30. Bourbos, E.; Giannopoulou, I.; Karantonis, A.; Paspaliaris, I.; Panias, D. Electrodeposition of Rare Earth Metals from Ionic Liquids. In Rare Earths Industry; Elsevier: Amsterdam, The Netherlands, 2016; pp. 199-207.

31. Abbott, A.P.; McKenzie, K.J. Application of Ionic Liquids to the Electrodeposition of Metals. Phys. Chem. Chem. Phys. 2006, 8, 4265. [CrossRef] [PubMed]

32. Reddy, R.G. Emerging Technologies in Extraction and Processing of Metals. Metall. Mater. Trans. B 2003, 34, 137-152. [CrossRef]

33. Abbott, A.P.; Capper, G.; Davies, D.L.; Shikotra, P. Processing Metal Oxides Using Ionic Liquids. Miner. Process. Extr. Metall. 2006, 115, 15-18. [CrossRef]

34. Davris, P.; Balomenos, E.; Panias, D.; Paspaliaris, I. Selective Leaching of Rare Earth Elements from Bauxite Residue (Red Mud), Using a Functionalized Hydrophobic Ionic Liquid. Hydrometallurgy 2016, 164, 125-135. [CrossRef]

35. Binnemans, K.; Jones, P.T. Solvometallurgy: An Emerging Branch of Extractive Metallurgy. J. Sustain. Metall. 2017, 3, 570-600. [CrossRef]

36. Sajó, I.E. X-Ray Diffraction Quantitative Phase Analysis of Bayer Process Solids. In Proceedings of the 10th International Conference of ICSOBA, Bhubaneshwar, India, 23-30 November 2008; pp. 71-76.

37. Sajò, I.E. XDB Powder Diffraction Phase Analytical System, Version 3.107; Computer Software: Budapest, Hungary, 2005.

38. Vind, J.; Malfliet, A.; Bonomi, C.; Paiste, P.; Sajó, I.E.; Blanpain, B.; Tkaczyk, A.H.; Vassiliadou, V.; Panias, D. Modes of Occurrences of Scandium in Greek Bauxite and Bauxite Residue. Miner. Eng. 2018, 123, 35-48. [CrossRef]

39. Vind, J.; Malfliet, A.; Blanpain, B.; Tsakiridis, P.; Tkaczyk, A.; Vassiliadou, V.; Panias, D. Rare Earth Element Phases in Bauxite Residue. Minerals 2018, 8, 77. [CrossRef]

(c) 2018 by the authors. Licensee MDPI, Basel, Switzerland. This article is an open access article distributed under the terms and conditions of the Creative Commons Attribution (CC BY) license (http://creativecommons.org/licenses/by/4.0/). 